Pawee Wojciechowski ${ }^{1}$

\title{
Kilka uwag o samoregulacji w łańcuchu żywnościowym w kontekście regulacji prawa publicznego
}

\section{Wstęp}

Od wielu już lat można obserwować zjawisko polegające na ustalaniu przez podmioty prywatne, uczestników rynku, z wykorzystaniem instrumentów prywatnoprawnych, pewnych zasad i reguł obowiązujących na rynkach, na których prowadzą one działalność 2 . Tego rodzaju oddolne inicjatywy pojawiły się także wśród podmiotów prowadzących przedsiębiorstwa spożywcze, które na zasadzie samoregulacji zaczęły tworzyć prywatne dobrowolne standardy, których celem było wdrażanie wymagań wynikających z prawa publicznego, ale przy jednoczesnym osadzeniu ich w stosunkach umownych, co pozwoliło też na usunięcie różnego rodzaju wątpliwości związanych ze stosowaniem norm prawnych, a przez to przyczyniło się do zwiększenia ochrony konsumentów ${ }^{3}$. Czynnikiem istotnie wpływającym na rozwój tego rodzaju współpracy w sektorze żywnościowym był ogromny wzrost handlu międzynarodowego, przy jednoczesnym zróżnicowaniu wymogów dotyczących żywności w różnych państwach świata, co skłaniało uczestników łańcucha żywnościowego do poszukiwania rozwiązań pozwalających na jednoznaczne ustalenie wymagań i oczekiwań dotyczących środków spożywczych, stawianych przez stronę sprzedającą i kupującą, w czym ogromnie pomocna okazała się samoregulacja ${ }^{4}$.

Okolicznością, która przyczyniła się do rozwoju samoregulacji, było też wydłużanie łańcucha rolno-żywnościowego, związane z rozwojem rynku żywności wysoko przetworzonej dystrybuowanej na rynku globalnym. W takim przypadku w wytwarzanie i dystrybucję żywności zaangażowanych jest wiele podmiotów po-

$1 \quad$ Uniwersytet Warszawski. Publikacja dofinansowana przez Uniwersytet Warszawski.

2 Zob. A. Mokrysz-Olszyńska, Rola kodeksów dobrych praktyk w ochronie konsumenta, (w:) C. Banasiński (red.), Ochrona konkurencji i konsumentów w Polsce i Unii Europejskiej (studia prawno-ekonomiczne), Warszawa 2005, s. 267.

3 Zob. N. Coutrelis, Foreword, (w:) Private food law, B. van der Meulen (red.), Wageningen 2011, s. 21.

4 Zob. L. Busch, Quasi-states? The unexpected rise of private food law, (w:) Private food law, B. van der Meulen (red.), Wageningen 2011, s. 59. 
chodzących z różnych państw (bardzo często surowce sprowadzane są z państw trzecich), a ustalenie jednolitych standardów zdecydowanie ułatwia taką wielostopniową współpracę

Na rozwój samoregulacji wpływa też zwiększająca się popularność odpowiedzialności społecznej biznesu (corporate social responsibility) oraz szczególne wymogi związane z wyznawaną religią (żywność halal dla społeczności muzułmańskiej, koszerna dla żydowskiej) ${ }^{6}$.

Oparcie tych inicjatyw na instrumentach prawa prywatnego, w sytuacji gdy działalność w zakresie wytwarzania, przetwarzania i dystrybucji żywności objęta jest bardzo szczegółową regulacją publicznoprawną, skłania do zadania pytania o zasadność podejmowania tego rodzaju działań w sektorze spożywczym oraz wzajemną relację samoregulacji i norm prawa publicznego. Powstaje też pytanie, czy samoregulacja może, a jeśli tak, to w jakim stopniu, zastąpić szczegółowe, nierzadko wręcz techniczne, unormowania prawa żywnościowego oraz czy samoregulacja może realizować cele prawa żywnościowego?

Celem niniejszego opracowania jest przedstawienie kilku refleksji dotyczących zakresu samoregulacji w łańcuchu rolno-żywnościowym i relacji samoregulacji do norm prawa publicznego. Artykuł ten stanowi jedynie punkt wyjścia do dalszej dyskusji w tym zakresie.

\section{Pojęcie samoregulacji}

Samo pojęcie samoregulacji nie jest zdefiniowane normatywnie ani w prawie krajowym, w prawie unijnym, ani na szczeblu międzynarodowym. Pojęcie to jest jednak często wykorzystywane w literaturze (w szczególności w opracowaniach z zakresu ochrony konkurencji i konsumenta, reklamy i mediów) ${ }^{7}$, a także w różnego rodzaju dokumentach unijnych o charakterze niewiążącym prawnie ${ }^{8}$. W literaturze można spotkać różne definicje samoregulacji (self-regulation). Wskazuje się, że oznacza ona wszelkie formy regulacji, które nie są wprowadzane w drodze ustawowo określonej procedury stanowienia prawa i nie są egzekwowane w drodze po-

Zob. B. van der Meulen, The anatomy of private food law, (w:) Private food law, B. van der Meulen (red.), Wageningen 2011, s. 77.

$6 \quad$ Zob. B. van der Meulen, The anatomy of private food law..., op. cit., s. 89

$7 \quad$ Zob. np. M. Kolasiński, Samoregulacja działalności reklamowej w Polsce - szanse oraz zagrożenia dla ochrony konkurencji i konsumentów, Internetowy Kwartalnik Antymonopolowy i Regulacyjny 2016, nr 1(5), www.ikar. wz.uw.edu.pl (data dostępu: 5.11.2018); A. Mokrysz-Olszyńska, Rola kodeksów dobrych praktyk..., op. cit.; N. Gunningham, J. Rees, Industry Self-Regulation: An Institutional Perspective, „Law \& Policy”, Vol. 19, No. 4, October 1997; L. Senden, Soft Law, Self-Regulation And Co-Regulation In European Law: Where Do They Meet?, „Electronic Journal of Comparative Law”, vol. 9.1 (January 2005) (data dostępu: 12.11. 2018); Ch.T. Marsden, Co- and Self-regulation in European Media and Internet Sectors: The Results of Oxford University's Study, (w:) Ch. Möller, A. Amouroux (eds), Representative on Freedom of Media, The Media Freedom Internet Cookbook, Viena 2004, 76-100, https://www.osce.org/fom/13844?download=true (data dostępu: 12.11.2018).

8 Zob. Parlament Europejski, Rada UE i Komisja WE, Porozumienie międzyinstytucjonalne w sprawie lepszego stanowienia prawa, Dz. Urz. z 31.12.2003 r., C 321/1. 
stępowania przed sądami państwowymi, a zasady określające postępowanie na rynku są ustalane, monitorowane i egzekwowane przez członków społeczności (lub ich bezpośrednich reprezentantów), której postępowanie jest przedmiotem regulacji ${ }^{9}$. Określa się ją także jako oddolne i całkowicie dobrowolne samozdyscyplinowanie się podmiotów prowadzących działalność w określonej branży poprzez przyjęcie pewnych reguł postępowania oraz utworzenie systemu zapewniającego ich przestrzeganie $^{10}$. Wskazuje się, że jest oparta na negocjacjach i porozumieniu między różnymi zainteresowanymi stronami (korporacjami, różnymi organizacjami, np. konsumenckimi) ${ }^{11}$.

Pojęcie to obejmuje swoim zakresem różnego rodzaju standardy, procedury, kodeksy dobrych praktyk (np. stosowanych w odniesieniu do reklamy żywności kierowanej do dzieci), kodeksy etyczne (np. różne systemy fair trade w produkcji i dystrybucji żywności), polityki (np. prywatności lub ochrony danych) tworzone przez różnego rodzaju podmioty, o charakterze niewiążącym prawnie, przeznaczone do dobrowolnego stosowania, ale także prywatne systemy certyfikacji i akredytacji służące weryfikacji wypełniania tych dobrowolnych norm ${ }^{12}$.

Cechą wyróżniającą samoregulację jest to, że różnego rodzaju reguły odnoszące się do określonego rodzaju działalności, opracowane przez zróżnicowane podmioty, są przyjmowane do stosowania samodzielnie przez poszczególnych uczestników rynku i na skutek ich dobrowolnej decyzji stają się dla tych podmiotów wiążące, pomimo tego, że nie są prawem (nie są normami prawnie wiążącymi) ${ }^{13}$. Ich obowiązywanie jest wynikiem zastosowania umów cywilnoprawnych zawieranych pomiędzy podmiotami uczestniczącymi w łańcuchu żywnościowym lub dodatkowo podmiotami tworzącymi te reguły. Mechanizm prawny przestrzegania przyjętych przez dany podmiot dobrowolnych standardów nie tkwi zatem w tych standardach (normach postępowania), ale znajduje się on w prawie cywilnym (należy dochowywać zawartych umów $)^{14}$. Ponadto, jeśli przedsiębiorca komunikuje swoim partnerom handlowym lub konsumentom, że przestrzega określonych standardów, wskaza-

9 Zob. A. Mokrysz-Olszyńska, Rola kodeksów dobrych praktyk..., op. cit., s. 267.

10 Zob. np. M. Kolasiński, Samoregulacja działalności reklamowej w Polsce - szanse oraz zagrożenia dla ochrony konkurencji i konsumentów..., op. cit., s. 62.

11 Zob. Ch.T. Marsden, Co- and Self-regulation in European Media and Internet Sectors: The Results of Oxford University's Study..., op. cit., s. 76.

12 Zob. D. Castro, Benefits and Limitations of Industry Self-Regulation for Online Behavioral Advertising, http:// www.itif.org/files/2011-self-regulation-online-behavioral-advertising.pdf (data dostępu: 15.11.2018); P. Wojciechowski, Prywatne prawo żywnościowe, (w:) M. Korzycka, P. Wojciechowski, System prawa żywnościowego, Warszawa 2017, s. 471.

13 Zob. B. van der Meulen, The anatomy of private food law..., op. cit., s. 75; D. Castro, Benefits and Limitations..., op. cit.

14 Zob. B. van der Meulen, The anatomy of private food law..., op. cit., s. 76; P. Wojciechowski, Prywatne prawo żywnościowe..., op. cit., s. 472. 
nych procedur, kodeksów lub polityk, staje się to elementem jego oferty handlowej, a kontrahent lub konsument może żądać od przedsiębiorcy wywiązania się ze swojej oferty ${ }^{15}$. Zobowiązanie takie ma charakter czysto cywilnoprawny.

Systematyzacja i klasyfikacja instrumentów wchodzących w zakres tak szeroko rozumianej samoregulacji może być dokonana na podstawie zróżnicowanych kryteriów, takich jak: kryterium podmiotowe, zakres oddziaływania (branże działalności), przedmiot samoregulacji (np. dotycząca produktu, procesu produkcji lub dystrybucji), sposób informowania (np. reklama określonych produktów), relacje z konsumentami (B2C) lub z kontrahentami (B2B), sposób poświadczania (np. deklaracja własna, audyt zewnętrzny, certyfikat $)^{16}$.

Ze względu na to, że samoregulacja oparta jest na systemie prawa cywilnego, instrumenty służące do egzekwowania podjętych w ramach samoregulacji zobowiązań także mają charakter cywilnoprawny. W przypadku naruszenia zobowiązania wynikającego z określonych standardów podmiot dopuszczający się takiego zachowania ponosi odpowiedzialność cywilnoprawną kontraktową wobec swoich partnerów handlowych. W zależności od rozwiązań przyjętych w określonym systemie samoregulacji (o ile przystąpienie następuje poprzez podpisanie odpowiedniej umowy) lub od treści umów handlowych zawartych pomiędzy przedsiębiorcami uczestniczącymi w łańcuchu żywnościowym (jeśli przedsiębiorca jedynie deklaruje zgodność swojej działalności z określonym standardem), podmiot dopuszczający się naruszenia przyjętych na siebie zobowiązań może ponieść konsekwencje polegające przede wszystkim na rozwiązaniu umowy współpracy z odbiorcami swoich produktów lub na konieczności zapłaty odszkodowania, w tym ewentualnie określonych w umowach kar umownych. Uczestnicy systemów samoregulacyjnych mogą dochodzić swoich praw przed sądami powszechnymi lub ewentualnie trybunałami arbitrażowymi, o ile wynika to z zawartych umów ${ }^{17}$.

W wielu opracowaniach podkreśla się też, że obok samoregulacji (self-regulation), niezmiernie istotną rolę może odgrywać współregulacja (co-regulation), która jest wyrazem dialogu pomiędzy zainteresowanymi podmiotami prywatnymi działającymi na określonym rynku a organami państwa ${ }^{18}$. W przypadku współregulacji $\mathrm{w}$ tworzenie norm poza podmiotami prywatnymi, zaangażowane są podmioty publicznoprawne, których zakres uprawnień do współpracy (które mogą polegać w szczególności na uprawnieniach nadzorczych) wynika z przepisów prawa ${ }^{19}$. Skutkiem takiego rozwiązania jest to, że co prawda to zainteresowane podmioty prywatne proponują określone rozwiązania, co jest analogiczne jak w przypadku samo-

Zob. B. van der Meulen, The anatomy of private food law..., op. cit., s. 76.

Szerzej zob. P. Wojciechowski, Prywatne prawo żywnościowe..., op. cit., s. 472 i n.

Zob. P. Wojciechowski, Prywatne prawo żywnościowe..., op. cit., s. 477.

Zob. Ch.T. Marsden, Co- and Self-regulation in European Media and Internet Sectors..., op. cit., s. 80

Zob. A. Mokrysz-Olszyńska, Rola kodeksów dobrych praktyk..., op. cit., s. 267. 
Kilka uwag o samoregulacji w łańcuchu żywnościowym w kontekście regulacji...

regulacji, ale dochodzi tu element dodatkowy, tj. możliwość ingerencji podmiotu publicznoprawnego. Rozwiązanie takie w istocie wyłącza pełną autonomię stron zaangażowanych w tworzenie dobrowolnych norm, co z kolei charakteryzuje samoregulację. Jak się wskazuje, jest to koncepcja umiejscowiona w połowie drogi pomiędzy regulacją publicznoprawną a ,czystą" samoregulacją ${ }^{20}$.

\section{Samoregulacja a cele prawa żywnościowego}

Postrzeganie samoregulacji uzależnione jest od sektora gospodarki, w którym jest ona wykorzystywana. Inne są cele, funkcje i zadania samoregulacji na rynku mediów, a inne w sektorze żywnościowym, bo też inne są cele i zasady prawa medialnego czy prawa reklamy, a inne prawa żywnościowego. W niniejszym artykule samoregulacja analizowana jest jako jeden $\mathrm{z}$ instrumentów realizacji celów prawa żywnościowego. W tym kontekście warto zatem przypomnieć, że stosownie do rozporządzenia nr 178/2002²1, wyodrębnić można ogólne cele prawa żywnościowego, którymi są: 1) zapewnienie wysokiego poziomu ochrony życia i zdrowia ludzkiego; 2) ochrona interesów ekonomicznych konsumenta; 3) zagwarantowanie rzetelności transakcji handlowych (przy czym ten cel nie jest ujmowany samodzielnie) oraz 4) zapewnienie swobodnego przepływu żywności w Unii Europejskiej (w przypadku tego celu mowa jest o „osiągnięciu”, a nie „realizacji”, oraz został on zawężony wyłącznie do żywności zgodnej z wymaganiami prawa żywnościowego), a także cele szczegółowe, mające zastosowanie „tam, gdzie to właściwe”, do których zalicza się: 1) ochrona zdrowia i warunków życia (dobrostanu) zwierząt i zdrowia roślin oraz 2) ochrona środowiska ${ }^{22}$. O ile nie budzi wątpliwości, iż samoregulacja może być jednym z instrumentów przyczyniających się do osiągnięcia tych celów, powstaje pytanie o zakres, w jakim może być ona wykorzystywana.

Uwagę warto więc skupić na dwóch podstawowych celach prawa żywnościowego, tj. wysokim poziomie ochrony zdrowia i życia konsumentów oraz ochronie interesów ekonomicznych konsumenta. Jednakże zaznaczyć trzeba, że i pozostałe cele nie pozostają bez znaczenia, tym bardziej że ochrona dobrostanu zwierząt i ochrona środowiska coraz częściej postrzegane są przez konsumentów jako istotne czynniki wyboru żywności (to właśnie potrzeba ochrony zwierząt i środowiska są głównymi przesłankami zmiany przez konsumentów diety na wegetariańską)23.

20 Zob. Ch.T. Marsden, Co- and Self-regulation in European Media and Internet Sectors..., op. cit., s. 80.

21 Rozporządzenie nr 178/2002 - rozporządzenie Parlamentu Europejskiego i Rady (WE) nr 178/2002 z dnia 28 stycznia 2002 r. ustanawiające ogólne zasady i wymagania prawa żywnościowego, powołujące Europejski Urząd ds. Bezpieczeństwa Żywności oraz ustalające procedury w sprawie bezpieczeństwa żywności (Dz. Urz. UE L 31 z 01.02.2002 r., s. 1).

22 Zob. art. 5 rozporządzenia nr 178/2002; zob. też. P. Wojciechowski, Cele prawa żywnościowego, (w:) M. Korzycka, P. Wojciechowski, System..., op. cit., s. 122; B. van der Meulen, The System of Food Law..., op. cit., s. 310.

23 Zob. V. Greenwood, Swapping t-bone for tofu - but does it add up?, http://www.bbc.com/capital/story/ 20181102-swapping-t-bone-for-tofu---but-does-it-add-up, (data dostępu: 12.11.2018). Przykładowo, w samym Londynie w 2018 r. aż 168000 osób zdecydowało się przystąpić do projektu polegającego na przejściu na wege- 
Niewątpliwie ochrona zdrowia i życia konsumentów jest podstawowym celem prawa żywnościowego, co wynika przede wszystkim z tego, że objęte tym celem dobra są usytuowane najwyżej w hierarchii dóbr konstytucyjnie chronionych ${ }^{24}$. Biorąc pod uwagę sposób normalnego użycia żywności polegający na jej spożywaniu, naruszenie tych dóbr jest ściśle związane z powstaniem szkód na osobie, w przypadku spożycia niebezpiecznego produktu żywnościowego. Obejmują one uszczerbki polegające na uszkodzeniu ciała, rozstroju zdrowia lub pozbawieniu życia. Uszczerbki te mogą przybrać postać zarówno szkody majątkowej, jak i niemajątkowej (krzywdy). W przypadku krzywd, odszkodowanie stanowi jedynie majątkową rekompensatę, zadośćuczynienie, gdyż skutki są w istocie nieodwracalne. Ponadto, niezwykle trudne jest postępowanie dowodowe, a zatem nawet w sytuacji zaistnienia szkody na osobie, ustalenie podmiotu odpowiedzialnego nie jest łatwe (w szczególności biorąc pod uwagę różne przesłanki egzoneracyjne $)^{25}$. Ze względu na znaczenie tych dóbr chronionych, ale i konsekwencje ich naruszenia, w pełni zasadne jest uznanie, iż to rolą państwa jest zapewnienie ochrony zdrowia i życia konsumentów żywności (a państwo może część swoich kompetencji w tym zakresie powierzyć organizacji międzynarodowej, i tak dzieje się w przypadku Unii Europejskiej). To zatem normy publicznoprawne muszą określać „standard minimum”, wyznaczając podstawowe wymogi mające na celu zapewnienie bezpieczeństwa żywności (m.in. wymogi odnośnie składu, dopuszczalnych poziomów zanieczyszczeń, wymogów higienicznych przy produkcji ${ }^{26}$ ). Poza tym, należy zwrócić uwagę na istotną asymetrię informacyjną. Konsument nie jest w stanie ustalić, w jaki sposób należy zorganizować produkcję i dystrybucję, tak aby zapewnić bezpieczeństwo żywności, a tym bardziej nie jest w stanie zweryfikować sposobu jej prowadzenia (nie ma bowiem dostępu do informacji o samym procesie produkcji i dystrybucji). Z kolei sami przedsiębiorcy nie mają też instrumentów dla prostego zweryfikowania, czy pozostali uczestnicy rynku, będący ich konkurentami, spełniają wymogi w tym zakresie, a zatem konieczna jest interwencja publicznoprawna, zarówno dla ustalenia wymogów, jak i dla ich egzekwowania. Z powyższych względów nie jest dopuszczalne, aby w zakresie wymogów dotyczących bezpieczeństwa żywności samoregulacja, a nawet współregulacja mogła zastąpić przepisy prawa. Samoregulacja może natomiast stanowić czynnik ułatwiający wdrożenie, nierzadko bardzo złożonych, norm prawa publicznego w działalności określonego przedsiębiorcy. Szczególnie pomocne mogą być w tym zakresie różne systemy certyfikacji powiązane z zewnętrznym audytem sprawdzającym stopień wdrożenia norm prawa publicznego lub prywatnych standardów, zgodnych jednak z tymi normami.

tarianizm na okres próby, podczas gdy w 2014 roku było to tylko 3300 osób, co pokazuje skalę zmian nawyków żywieniowych. ściowy pierwotny i przetworzony. Wybrane problemy, „Studia luridica Agraria”, Tom IX 2011, s. 328 i n. 
Nieco inaczej przedstawia się sytuacja norm nakierowanych na ochronę drugiego z podstawowych celów prawa żywnościowego, tj. ochrony interesów ekonomicznych konsumentów, który jest ściśle powiązany z ochroną uczciwych praktyk w handlu żywnością̨ . W tym przypadku naruszenie chronionego dobra prowadzi do powstania szkody na mieniu. Konsument bądź przedsiębiorca, których interes został naruszony, ponoszą szkodę na mieniu, a instrumenty cywilnoprawne mogą doprowadzić do kompensaty poniesionej szkody. Co więcej, w tym przypadku naruszenia najczęściej są konsekwencją działań przedsiębiorców wynikających z nieuczciwej konkurencji. Chcąc zwiększyć sprzedaż swoich produktów stosują oni różne praktyki zmierzające do wyróżnienia tych produktów. Naruszenia najczęściej związane są zatem z niewłaściwym znakowaniem produktów żywnościowych, czy szerzej to ujmując z niewłaściwym informowaniem o produktach. Tego rodzaju naruszenia mogą być $\mathrm{w}$ dużej części identyfikowane przez konsumentów lub konkurentów poprzez analizę informacji o produkcie. Oczywiście także i w tym przypadku występuje asymetria informacji, konsumenci mają mniejsze możliwości weryfikacji informacji prezentowanych przez przedsiębiorców, natomiast zdecydowanie mniejsza jest asymetria informacyjna pomiędzy podmiotami konkurencyjnymi. Przedsiębiorcy w dużej mierze mogą samodzielnie wykrywać naruszenia lub dokonywać oceny prawidłowości określonych praktyk. Możliwe jest zatem ustalenie jednolitych zasad informowania o określonych rodzajach żywności (np. suplementach diety) lub żywności przeznaczonej dla określonych grup konsumentów (np. dzieci i młodzieży, osób starszych itp.). W tym przypadku znaczenie samoregulacji mogłoby być zdecydowanie większe. Co więcej, wprowadzając określone dobrowolne normy, podmioty zainteresowane mogłyby podnosić standard jakościowy produktów. To właśnie realizacji tego celu mogą służyć różne prywatne systemy jakościowe, związane ze znakowaniem żywności określonym znakiem jakości. Warto zauważyć, że także ustawodawca upatruje możliwość wprowadzania systemów jakościowych w zakresie dotyczącym jakości żywności, wprowadzając publiczne systemy jakości żywności, takie jak produkcja ekologiczna czy żywność regionalna i tradycyjna (CHNP, ChOG, GTS). Obok tych publicznych systemów mogą pojawić się, i w praktyce pojawiają się, również inne systemy jakości oparte na samoregulacji. Jednak także i w tym przypadku nie wydaje się możliwe całkowite zrezygnowanie z regulacji publicznoprawnej, pewne minimum ochrony konsumenta wymaga zastosowania instrumentów publicznoprawnych. Jest to spowodowane przede wszystkim tym, że samoregulacja ma charakter dobrowolny, a zatem nie musi objąć wszystkich podmiotów. Poza tym, o ile regulacje publicznoprawne nastawione są na ochronę interesu publicznego konsumentów, o tyle samoregulacja nakierowana będzie w głównej mierze na ochronę podmiotów, które przystąpiły do danego syste-

27 Zob. art. 5 rozporządzenia nr 178/2002, w którym jako zadanie prawa żywnościowego wskazuje się realizację „celów dotyczących (...) ochrony interesów konsumentów, z uwzględnieniem uczciwych praktyk w handlu żywnością (...)". 
mu, przed nieuczciwymi praktykami innych podmiotów, a ochrona konsumenta jest niejako efektem ubocznym. W sytuacji zatem, gdy przy ustalaniu norm wiążących uczestników danego systemu samoregulacji konieczne będzie wyważenie interesu konsumentów z interesem przedsiębiorców, trudno oczekiwać, że podmioty działające w celu zarobkowym dobrowolnie zrezygnują ze swoich potencjalnie wyższych dochodów, na rzecz lepszej (ponadstandardowej) ochrony konsumentów. Pewnym remedium na tego rodzaju zagrożenia może być natomiast przekształcenie systemu jakości opartego na samoregulacji w system oparty na współregulacji.

Samoregulacja może też przyczyniać się do realizowania pozostałych celów prawa żywnościowego, w szczególności ochrony zdrowia i dobrostanu zwierząt oraz ochrony środowiska. Charakterystyczne jest jednak, że w przypadku tych dwóch celów systemy samoregulacyjne nie tyle nastawione są wprost na ich realizację, co raczej poprzez szczególną dbałość o środowisko lub dobrostan zwierząt, uzyskuje się przewagę konkurencyjną u konsumentów, dla których te dwa dobra stoją wysoko w ich hierarchii wartości i są skłonni zapłacić więcej za produkty uzyskiwane w sposób sprzyjający środowisku lub dobrostanu zwierząt. Powiązanie szczególnej ochrony tych dóbr z ochroną konsumenta jest widoczne też w niektórych regulacjach z zakresu prawa żywnościowego. Przykładowo, prawodawca nie poprzestał na uregulowaniu minimalnych norm ochrony kur niosek ${ }^{28}$, ale w przepisach dotyczących znakowania jaj kurzych wymaga zamieszczenia informacji o sposobie chowu ${ }^{29}$. Podobnie w przypadku regulacji dotyczącej produkcji metodami ekologicznymi, prawodawca wprost wskazuje, że ten rodzaj produkcji z jednej strony jest odpowiedzią na zapotrzebowanie konsumentów, bo dostarcza na rynek produkty ekologiczne, a z drugiej dostarcza powszechnie dostępne dobra, przyczyniając się do ochrony środowiska i dobrostanu zwierząt, jak również do rozwoju obszarów wiejskich ${ }^{30}$.

\section{Samoregulacja w łańcuchu rolno-żywnościowym}

Nie tylko cele danej dziedziny prawa wpływają na postrzeganie samoregulacji na określonym rynku, znaczenie ma też specyfika rynku. Sektor żywnościowy charakteryzuje ogromne zróżnicowanie. Wynika ono z wielu czynników, w tym z samej różnorodności środków spożywczych (z jednej strony płody rolne, z drugiej suplementy diety), z rodzajów prowadzonej działalności (produkcja rolnicza, przetwarzanie, dystrybucja) czy z bardzo dużych różnic co do skali prowadzonej dzia-

28 Dyrektywa Rady 1999/74/WE z dnia 19 lipca 1999 r. ustanawiająca minimalne normy ochrony kur niosek (Dz.U. L 203 z 3 sierpnia 1999, s. 53).

29 Rozporządzenie Komisji (WE) nr 589/2008 z dnia 23 czerwca 2008 r. ustanawiające szczegółowe zasady wykonywania rozporządzenia Rady (WE) nr 1234/2007 w sprawie norm handlowych w odniesieniu do jaj.

30 Zob. pkt 1 preambuły do Rozporządzenia Parlamentu Europejskiego i Rady (UE) 2018/848 z dnia 30 maja 2018 r. w sprawie produkcji ekologicznej i znakowania produktów ekologicznych i uchylające rozporządzenie Rady (WE) nr 834/2007 (Dz.U. L 203 L 150 z 14 czerwca 2018, s. 1). 
Kilka uwag o samoregulacji w łańcuchu żywnościowym w kontekście regulacji...

łalności (od rolników indywidualnych i mikroprzedsiębiorców, po ogromne korporacje międzynarodowe). Specyfiką sektora żywnościowego jest też zaangażowanie w łańcuch rolno-żywnościowy bardzo dużej liczby podmiotów. Niejednokrotnie na efekt w postaci umieszczenia produktu w sklepie składa się działalność kilku lub kilkunastu podmiotów, począwszy od produkcji pierwotnej, przetwarzania, przewozu, dystrybucji. Co więcej, specyfika żywności powoduje, iż jakakolwiek nieprawidłowość na którymkolwiek etapie łańcucha rolno-żywnościowego może prowadzić do zagrożenia dla dóbr chronionych (przede wszystkim zdrowia i życia oraz interesu ekonomicznego konsumenta) na każdym etapie łańcucha rolno-żywnościowego. Dodatkowym problemem są także bardzo złożone relacje handlowe pomiędzy tymi podmiotami (np. sieci handlowe sprzedające produkty pod swoją marką). Nie bez znaczenia pozostają też oczekiwania i postawy konsumentów, którzy coraz częściej poszukują żywności określonego rodzaju i o szczególnych właściwościach, co ma związek z modą na zdrowy styl życia ${ }^{31}$. Uczestnicy łańcucha rolno-żywnościowego, starając się im sprostać, wykorzystują do tego celu różne środki, polegające nie tylko na wprowadzaniu nowych rodzajów produktów, ale przede wszystkim na stosowaniu różnego rodzaju technik marketingowych. W szczególności na etykietach i w reklamie żywności wykorzystywane są informacje dobrowolne, które mają zwrócić uwagę na szczególne właściwości określonego produktu (np. informacje o braku zawartości określonych substancji ${ }^{32}$. W tym rozbudowanym łańcuchu żywnościowym i przy ogromnej presji rynkowej na uczestników tego łańcucha jednym z najistotniejszych czynników współpracy stają się zaufanie i pewność uczestników tego łańcucha, że na wszelkich wcześniejszych etapach łańcucha rolno-żywnościowego zachowane były standardy, których oczekują konsumenci ${ }^{33}$.

Może to być osiągnięte przez zawieranie bardzo szczegółowych umów określających wszelkie wymogi odnośnie zamawianych produktów i zasad kontroli, weryfikacji itp. Wadą tego rozwiązania jest jednak to, że dla każdego produktu niezbędne jest tworzenie odrębnej umowy i negocjowanie jej z każdym z dostawców. Poza tym, złożoność procesów wytwórczych i dystrybucyjnych oraz zróżnicowanie wymogów prawnych na różnych rynkach powoduje, że dla zapewnienia bezpieczeństwa i oczekiwanej przez konsumenta jakości nie są już wystarczające umowy cywilnoprawne, i to nie tylko te najprostsze określające przedmiot zamówienia, ilość i cenę, ale nawet te bardziej złożone określające szczegółowo wymogi dotyczące produktu, procesów jego wytwarzania i dystrybucji ${ }^{34}$. Instrumentem pozwalającym na uzyskanie odpowiedniej jakości produktu końcowego poprzez zapewnienie oczekiwanej jakości na wszystkich wcześniejszych etapach łańcucha żywnościowego

31 Zob. Ł.M. Sokołowski, Prawne aspekty wprowadzania nowej żywności na rynek unijny, Poznań 2017, s. 21.

32 Zob. szerzej P. Wojciechowski, Informacja o braku zawartości określonych substancji w żywności w regulacjach prawa żywnościowego, „Przegląd Prawa Rolnego” 2018, nr 1, s. 103 i n.

33 Zob. P. Wojciechowski, Prywatne prawo żywnościowe, (w:) System..., op. cit., s. 470.

34 Zob. B. van der Meulen, The anatomy of private food law..., op. cit., s. 77. 
jest system samoregulacji, który można w tym kontekście określić jako instrument „współgrania łańcuchowego" (chain orchestration) ${ }^{35}$.

W przemyśle żywnościowym szczególne znaczenie na rynku globalnym mają prywatne systemy samoregulacji, obejmujące wprowadzanie dobrowolnych standardów i certyfikację, np. GlobalGAP (działający od 1997 r. początkowo jako EuroGAP), BRC (British Retail Consortium - działający od 1998 r.), IFS (International Food Standard - rozwijany od 2002 r. początkowo w Niemczech, potem także we Francji), SQF (Safe Quality Food - tworzony na rynku australijskim i amerykańskim), GFSI (The Global Food Safety Initiative) ${ }^{36}$.

Standard w tym ujęciu oznacza zestaw ustalonych przez podmiot prywatny wymagań, które dotyczyć mogą określonego produktu, procesów związanych z wytwarzaniem i dystrybucją lub sposobu informowania o określonych produktach. Czynnikiem, który pozwala zaliczyć standardy do zakresu samoregulacji, jest to, że ma charakter norm dobrowolnych i jest ustanawiany przez podmiot lub podmioty prywatne. Zwykle podmioty przygotowujące standardy same są zaangażowane w określony rodzaj działalności (np. stowarzyszenia czy zrzeszenia producentów, dystrybutorów itp.) lub są wyrazicielami woli tych podmiotów. Warto przy tym zaznaczyć, że poza podmiotami prywatnymi, standardy o charakterze dobrowolnym tworzone są też przez podmioty, które nie mają już charakteru prywatnoprawnego, jak np. standardy tworzone przez Komisję Kodeksu Żywnościowego, działającą w ramach Wspólnego Programu dla Norm Dotyczących Żywności, powołanego przez Organizację NZ ds. Wyżywienia i Rolnictwa (FAO) oraz Światową Organizację Zdrowia (WHO), które określane są ogólną nazwą „Codex Alimentarius”, lub przez Międzynarodową Organizację Standaryzacji (International Organization for Standardization - ISO). Często te dwa pojęcia, tj. „standardy prywatne” (private standards) i ,dobrowolne standardy” (voluntary standards), używane są zamiennie, chociaż nie jest to prawidłowe ${ }^{37}$. W sektorze żywnościowym to standardy wchodzące w zakres Kodeksu żywnościowego mają kluczowe znaczenie. Co więcej, nierzadko są one przyjmowane jako faktyczna podstawa dla przyjmowanych rozstrzygnięć legislacyjnych. Standardy prywatne stanowią jednak swego rodzaju „urozmaicenie” możliwości dla przedsiębiorców, w szczególności mogą one określać wymagania dalej idące, niż wynika to z dobrowolnych standardów międzynarodowych (np. z Codex Alimentarius), a zastosowanie się do nich pozwala przedsiębiorcom na podwyższenie jakości ich produktów.

Tak B. van der Meulen, The anatomy of private food law..., op. cit., s. 78; zob. też P. Wojciechowski, Prywatne prawo żywnościowe..., op. cit., s. 471.

Prywatne standardy szeroko omówione zostały przez m.in. T. Appelhof, R. van den Heuve, Inventory of private food law, (w:) Private food law..., op. cit., s. 113-147; B. van der Meulen, The anatomy of private food law..., op. cit., s. 92-105.

Zob. S. Henson, J. Humphrey, Codex Alimentarius and private standards, (w:) Private food law..., op. cit., s. 152. 
Dalej idącym zakresem współpracy w ramach samoregulacji są systemy certyfikacji. W tym przypadku podmioty prywatne poza ustaleniem wymogów, jakich należy przestrzegać (standardu), ustalają też zasady weryfikowania dostosowania się do tego standardu, z czym związane jest uzyskanie potwierdzenia zgodności z tymi wymogami (certyfikatu). Certyfikacja może też dotyczyć zgodności ze standardem określonym przez inny podmiot. Istotą prywatnych systemów certyfikacji jest bowiem to, że podmioty trzecie, będące niezależnymi audytorami, sprawdzają czy dany podmiot poddający się certyfikacji spełnia wymagania objęte certyfikowanym standardem. W tym przypadku kluczową kwestią jest zapewnienie wysokiego profesjonalizmu i niezależności przez podmioty certyfikujące, a podstawowy problem polega na tym, że podmiot certyfikujący, z jednej strony, konkuruje z innymi podmiotami świadczącymi analogiczne usługi i w sytuacji, gdy stosuje zbyt rygorystyczne wymogi, traci klientów, którzy płacą za usługę i zainteresowani są uzyskaniem certyfikatu, a z drugiej strony, powinien rzetelnie zweryfikować, czy dany podmiot spełnia wymagania niezbędne dla uzyskania certyfikatu, tak aby udzielony certyfikat był godny zaufania ${ }^{38}$. Instrumentem służącym ujednoliceniu jakości certyfikacji przeprowadzanej przez konkurujące ze sobą podmioty jest akredytacja podmiotów certyfikujących, prowadzona w poszczególnych państwach przez organy administracji publicznej, podmioty prywatne realizujące zadania publiczne, którą stosuje się w wielu państwach ${ }^{39}$.

Różne są funkcje systemów samoregulacji w łańcuchu rolno-żywnościowym. Podstawową funkcją jest zwiększenie bezpieczeństwa obrotu i zaufania pomiędzy uczestnikami łańcucha żywnościowego, którzy poprzez odniesienie się do określonych, znanych obu stronom umowy, standardów są w stanie określić zakres wzajemnych wymagań, czego nie byliby w stanie zrobić nie dysponując nimi ${ }^{40}$. Poza tym, samoregulacja ma jednak też funkcję marketingową i to dwojakiego rodzaju. Z jednej strony, legitymowanie się określonym renomowanym certyfikatem lub deklarowanie zgodności z określonymi standardami, wpływa na zwiększenie konkurencyjności danego przedsiębiorcy u potencjalnych kontrahentów działających w łańcuchu żywnościowym (tj. business-to-business - B2B). Z drugiej strony, także konsumenci rozpoznają i pozytywnie reagują na niektóre nazwy lub symbole (znaki słowne lub graficzne), a ich zamieszczenie na etykiecie może wpływać na atrakcyjność produktów. Jest to wykorzystywane w niektórych systemach samoregulacji, gdy uzyskanie certyfikacji związane jest z prawem do posługiwania się określonym znakiem słowno-graficznym ${ }^{41}$. Tego rodzaju funkcje zaczynają również peł-

\footnotetext{
38 Zob. L. Busch, Quasi-states..., op. cit., s. 61 i 65; P. Wojciechowski, Prywatne prawo żywnościowe, (w:) System..., op. cit., s. 474.

39 Zob. L. Busch, Quasi-states..., op. cit., s. 61

40 Zob. P. Wojciechowski, Prywatne prawo żywnościowe, (w:) System..., op. cit., s. 478.

41 Zob. P. Wojciechowski, Prywatne prawo żywnościowe, (w:) System..., op. cit., s. 479.
} 
nić tzw. marki własne, będące niejako gwarancją jakości dawaną przez sieć sprzedaży ${ }^{42}$. Znaczenie samoregulacji $\mathrm{w}$ tym zakresie nabiera też znaczenia wraz z rosnącą świadomością społeczeństw dotyczącą zagrożeń dla środowiska, bioróżnorodności oraz zmian klimatu, a także zależności zachodzących pomiędzy dietą a zdrowiem. Konsumenci coraz częściej oczekują informacji dotyczących prowadzenia działalności w sposób przyjazny środowisku (zrównoważony) i chcą mieć pewność co do rzetelności tych informacji, a prywatne systemy certyfikacji stanowią dobry instrument dla wdrażania odpowiednich praktyk produkcyjnych ${ }^{43}$. Z funkcją marketingową samoregulacji, głównie skierowaną do konsumentów, związane jest jednak dodatkowe ryzyko polegające na tym, że mogą powstawać różne systemy odwołujące się do tej samej wartości pozytywnie postrzeganej przez konsumenta (np. fair trade, bez GMO), które jednak oparte są na zróżnicowanych, często niejasnych kryteriach, co w istocie prowadzić może do dezinformacji konsumenta (tego rodzaju ryzyko doprowadziło do wydania w latach 90 . regulacji dotyczącej produkcji metodami ekologicznymi) ${ }^{44}$.

Poddanie się przez danego przedsiębiorcę systemowi certyfikacji uznanemu przez swoich kontrahentów oznacza, że nie musi się on poddawać indywidualnej weryfikacji przez każdego z kontrahentów, a jednocześnie poszczególni kontrahenci nie muszą podejmować czynności zmierzających do zweryfikowania deklaracji tego podmiotu co do jakości oferowanych przez niego produktów ${ }^{45}$. W przypadku, gdy przedsiębiorca nie wypełnia wymogów koniecznych do uzyskania certyfikatu, certyfikat nie jest przyznawany, a uprzednio przyznany jest wycofywany, co w konsekwencji może prowadzić do zerwania współpracy z podmiotami wymagającymi posiadania określonej certyfikacji.

\section{Uwagi podsumowujące}

Zaletą dobrowolnych systemów standardów i certyfikacji w porównaniu z przepisami prawa jest to, że systemy te są bardziej elastyczne, łatwiej można je dostosować do zmieniających się potrzeb i zmian rynkowych, w większym stopniu uwzględniają różnice pomiędzy różnymi rodzajami żywności i działalności, a jednocześnie systemy te sprzyjają zapewnieniu nie tylko bezpieczeństwa żywności, ale nawet jakości wyższej od „standardu minimum”, oraz ułatwiają międzynarodowy obrót pro-

\footnotetext{
42 Na temat znaczenia marek własnych zob. szerzej F. Bunte i in., The impact of private labels on the competitiveness of the European food supply chain, Luxembourg 2011.

43 Zob. L.L. Sharma, S.P. Teret, K.D. Brownell, The Food Industry and Self-Regulation: Standards to Promote Success and to Avoid Public Health Failures, Am J Public Health. 2010 February; 100(2): 240-246. doi: 10.2105/AJPH.2009.160960, https://www.ncbi.nlm.nih.gov/pmc/articles/PMC2804645/\#bib44, (data dostępu: 29.01.2019).

44 Zob. P. Wojciechowski, Prywatne prawo żywnościowe, (w:) System..., op. cit., s. 479.

45 Zob. B. van der Meulen, The anatomy of private food law..., op. cit., s. 80.
} 
Kilka uwag o samoregulacji w łańcuchu żywnościowym w kontekście regulacji...

duktami żywnościowymi ${ }^{46}$. Stosowanie tych instrumentów pozwala na zmniejszenie ryzyka dla konsumentów (konsumenci są lepiej chronieni), zwiększenie zaufania publicznego oraz na zwalczanie negatywnych zjawisk na rynku ${ }^{47}$.

Z drugiej jednak strony można wskazać także wiele wad samoregulacji. Normy ustalane w jej ramach odzwierciedlają interesy różnych zaangażowanych podmiotów prywatnych i często pisane są językiem na tyle ogólnym, iż trudno jest jednoznacznie określić, czy doszło do ich naruszenia ${ }^{48}$. Poza tym, nie zawsze określone są procedury monitorowania i kontroli przestrzegania tych norm i nie ma możliwości nakładania sankcji na podmioty nieprzestrzegające tych norm. Sankcje mogą być bowiem nakładane na zasadzie umownej na podmioty przystępujące do systemów samoregulacji ${ }^{49}$. Ponadto, nie w każdym systemie samoregulacji są przewidziane sankcje, co zwykle prowadzi do obniżenia skuteczności takiego systemu ${ }^{50}$. Poza tym, są one wprowadzane często przez organizacje w dużej mierze zależne od potężnych korporacji międzynarodowych lub wprost są ustanawiane przez te korporacje działające ponadnarodowo. Nierzadko też pewne dobrowolne standardy stają się popularne i nabywcy (nie tylko najwięksi) wymagają ich wdrożenia przez dostawców ${ }^{51}$. W takim przypadku dostawca, jeśli chce utrzymać się na rynku, w praktyce musi wdrożyć standardy lub poddać się określonej certyfikacji ${ }^{52}$. Powoduje to, że niejako równolegle do systemu prawnego poszczególnych państw powstaje system norm niezależnych od państw, dobrowolnych i opartych na zasadzie równorzędności i autonomii stron, które jednak de facto stają się obowiązkowe dla podmiotów, które chcą utrzymać się na rynku, a zatem powstaje swego rodzaju system quasi-prawny tworzony przez quasi-państwa ${ }^{53}$. Co więcej, inaczej niż w przypadku norm publicznoprawnych tworzonych przez państwo (w którym w ramach trójpodziału władzy funkcjonują organy prawodawcze wybrane przez większość społeczeństwa), systemy prywatnych standardów często tworzone są przez organizacje zdominowane przez kilka największych podmiotów działających w danej branży spożywczej, bez żadnego mechanizmu demokratycznego ${ }^{54}$. Powoduje to, że przy tworzeniu instrumentów samoregulacji w większym stopniu niż przy tworzeniu prawa uwzględ-

46 Zob. L. Busch, Quasi-states..., op. cit., s. 63; D. Castro, Benefits and Limitations..., op. cit., s. 5; P. Wojciechowski, Prywatne prawo żywnościowe, (w:) System..., op. cit., s. 475.

47 Zob. D. Castro, Benefits and Limitations..., op. cit., s. 3 i 5.

48 Zob. H.W. Arthus, Corporate Self-regulation: Political Economy, State Regulation and Reflexive, (w:) Labour Law, B. Bercusson, E. Cynthia (eds.), Regulating Labour in the Wake of Globalisation. Oxford, UK: Hart Publishing, 2008. ISBN: 9781841137667, s. 6, http://digitalcommons.osgoode.yorku.ca/scholarly_works, (data dostępu: 11.12.2018).

49 Zob. A. King, M. Lenox, "Industry Self-Regulation Without Sanctions: The Chemical Industry's Responsible Care Program" (2000) 4 Academy of Management Journal 698, http://citeseerx.ist.psu.edu/viewdoc/download?doi=10.1.1.25.5891\&rep=rep1\&type=pdf, (data dostępu: 14.11.2018).

50 Zob. szerzej: A. King, M. Lenox, "Industry Self-Regulation Without Sanctions: The Chemical Industry's..., op. cit.

51 Zob. P. Wojciechowski, Prywatne prawo żywnościowe, (w:) System..., op. cit., s. 475.

52 Zob. B. van der Meulen, The anatomy of private food law..., op. cit., s. 76.

53 Zob. L. Busch, Quasi-states..., op. cit., s. 63; B. van der Meulen, The anatomy of private food law..., op. cit., s. 76 .

54 Zob. L. Busch, Quasi-states..., op. cit., s. 64. 
nia się interes określonych grup przedsiębiorców, zainteresowanych wprowadzeniem samoregulacji, a nie interes publiczny ${ }^{55}$. Decyzje podejmowane kolektywnie przez przedstawicieli przedsiębiorców, np. producentów żywności, są w istocie sumą decyzji indywidualnych, nakierowanych w przypadku działalności gospodarczej na osiągnięcie indywidualnego zysku, co ma szczególnie istotne znaczenie przy samoregulacji dotyczącej np. reklamy ${ }^{56}$.

Zasadnym jest uznanie, iż samoregulacja z całą pewnością nie może zastąpić norm publicznoprawnych w prawie żywnościowym, może natomiast stanowić instrument przyczyniający się do pełniejszego wykonywania norm prawa żywnościowego i do realizacji celów tego prawa.

Normy publicznoprawne muszą regulować standard bezpieczeństwa, będący „standardem minimum” dla środków spożywczych. Systemy samoregulacji mogą natomiast wprowadzać podwyższone standardy, odwołujące się zresztą do różnych wartości (np. obniżone zużycie energii, mniejsze obciążenie środowiska, odniesienie się do uczciwych metod produkcji). Zobowiązanie się poszczególnych uczestników łańcucha żywnościowego do przestrzegania takich podwyższonych standardów sprzyja realizacji celów prawa żywnościowego. Z kolei systemy certyfikacji przyczyniają się do zwiększenia pewności obrotu w łańcuchu żywnościowym i pozwalają na zapewnienie uczciwych zasad konkurowania podmiotów działających na określonym rynku, którzy są uczestnikami danego systemu samoregulacji. Systemy certyfikacji powinny podlegać jednak akredytacji, która w istocie nie dotyczy samego standardu, ale sposobu przeprowadzania jego weryfikacji.

Podsumowując można stwierdzić, że przystąpienie do systemu samoregulacji przez danego przedsiębiorcę ułatwia mu wypełnienie wymogów prawnych obowiązujących w innych państwach. Samoregulacja stanowi most pomiędzy różnymi systemami prawnymi ${ }^{57}$.

Wdrożenie prywatnego standardu jakości i poddanie się certyfikacji powinno stanowić też dowód dołożenia należytej staranności przez przedsiębiorcę, co powinno mieć znaczenie w przypadku dochodzenia odpowiedzialności cywilnej ${ }^{58}$. Wdrożenie tego rodzaju prywatnego systemu powinno być uwzględniane przez organy urzędowej kontroli żywności przy nakładaniu kar pieniężnych za naruszenie norm

Jak pokazuje historia, nierzadko samoregulacja w określonych branżach wprowadzana jest w odpowiedzi na pojawiające się oburzenie społeczne co do określonych praktyk i ma ona na celu głównie chronić podmioty z danej branży (np. tytoniowej). Wiele przykładów tego rodzaju samoregulacji opisano, (w:) L.L. Sharma, S.P. Teret, K.D. Brownell, The Food Industry and Self-Regulation: Standards to Promote Success and to Avoid Public Health Failures, Am J Public Health. 2010 February; 100(2): 240-246. doi: 10.2105/AJPH.2009.160960, https:// www.ncbi.nlm.nih.gov/pmc/articles/PMC2804645/\#bib44 , (data dostępu: 29.01.2019).

56 Zob. P. Wilde, Self-regulation and the response to concerns about food and beverage marketing to children in the United States, Nutrition Reviews 2009, vol. 67, nr 3, s. 159.

57 Zob. B. van der Meulen, The anatomy of private food law..., op. cit., s. 88

58 Zob. B. van der Meulen, The anatomy of private food law..., op. cit., s. 88. 
prawa żywnościowego, jako okoliczność wpływająca na obniżenie wysokości kary. Wdrożenie takiego systemu świadczy bowiem o tym, że przedsiębiorca podjął ponadstandardowe działania zmierzające do zwiększenia jakości wytwarzanych środków spożywczych, a poza tym opierając się na tych systemach, można m.in. ustalić, czy w danych okolicznościach można było przy zachowaniu należytej staranności uniknąć naruszenia czy też naruszenie w istocie było trudne do wykrycia i zapobieżenia $\mathrm{mu}^{59}$. Warto też zaznaczyć, że w niektórych państwach organy urzędowej kontroli żywności, opierając się na wdrożonych przez przedsiębiorców z państw trzecich systemach jakości, podejmują decyzję o dopuszczaniu na rynek unijny produktów wytworzonych w państwach trzecich przez te podmioty ${ }^{60}$.

59 Zob. P. Wojciechowski, Model odpowiedzialności administracyjnej w prawie żywnościowym, Warszawa 2015, s. 405 oraz s. 546.

60 Zob. B. van der Meulen, The anatomy of private food law..., op. cit., s. 88. 


\section{SOME REMARKS ON SELF-REGULATION IN THE FOOD CHAIN IN THE CONTEXT OF PUBLIC LAW REGULATION}

Keywords: Self-regulation, food chain, agri-food chain, goals of food law, co-regulation, public law

The phenomenon of self-regulation is becoming more and more widespread among the agri-food chain participants. Basing these initiatives on instruments of private law, raises the question of the legitimacy of taking such measures in the food sector and the relationship between self-regulation and public law, because the activity in the scope of production, processing and distribution of food is covered by a very detailed public law regulation.

The article attempts to answer such a question. The conclusions state that due to the scope of food law objectives and the specificity of food, it is not allowed to replace even specific food law norms with self-regulation. Self-regulation may, however, be an instrument for raising the standards of food products. It should also be legally considered when assessing the scope of liability of food business operators.

\section{Bibliografia:}

Appelhof T., van den Heuve R., Inventory of private food law, (w:) Private food law, B. van der Meulen (red.), Wageningen 2011.

Arthus H.W., Corporate Self-regulation: Political Economy, State Regulation and Reflexive, (w:) Labour Law, B. Bercusson, E. Cynthia (eds.), Regulating Labour in the Wake of Globalisation. Oxford, UK: Hart Publishing, 2008.

Bunte F. i in., The impact of private labels on the competitiveness of the European food supply chain, Luxembourg 2011.

Busch L., Quasi-states? The unexpected rise of private food law, (w:) Private food law, B. van der Meulen (red.), Wageningen 2011.

Castro D., Benefits and Limitations of Industry Self-Regulation for Online Behavioral Advertising, http://www.itif.org/files/2011-self-regulation-online-behavioral-advertising.pdf.

Coutrelis N., Foreword, (w:) Private food law, B. van der Meulen (red.), Wageningen 2011.

Greenwood V., Swapping t-bone for tofu - but does it add up?, http://www.bbc.com/capital/story/ 20181102-swapping-t-bone-for-tofu---but-does-it-add-up

Gunningham N., Rees J., Industry Self-Regulation: An Institutional Perspective, Law \& Policy, Vol. 19, No. 4, October 1997.

Henson S., Humphrey J., Codex Alimentarius and private standards, (w:) Private food law, B. van der Meulen (red.), Wageningen 2011.

King A., Lenox M., "Industry Self-Regulation Without Sanctions: The Chemical Industry's Responsible Care Program", (2000) 4 Academy of Management Journal 698. 
Kilka uwag o samoregulacji w łańcuchu żywnościowym w kontekście regulacji...

Kolasiński M., Samoregulacja działalności reklamowej w Polsce - szanse oraz zagrożenia dla ochrony konkurencji i konsumentów, Internetowy Kwartalnik Antymonopolowy i Regulacyjny 2016, nr 1(5), www.ikar.wz.uw.edu.pl (data dostępu: 5.11.2018).

Korzycka M., Wojciechowski P., System prawa żywnościowego, Warszawa 2017.

Marsden Ch.T., Co- and Self-regulation in European Media and Internet Sectors: The Results of Oxford University's Study, (w:) Ch. Möller, A. Amouroux (eds), Representative on Freedom of Media, The Media Freedom Internet Cookbook, Viena 2004, 76-100, https://www.osce.org/ fom $/ 13844$ ?download=true

Mokrysz-Olszyńska A., Rola kodeksów dobrych praktyk w ochronie konsumenta, (w:) C. Banasiński (red.), Ochrona konkurencji i konsumentów w Polsce i Unii Europejskiej (studia prawno-ekonomiczne), Warszawa 2005.

Senden L., Soft Law, Self-Regulation And Co-Regulation In European Law: Where Do They Meet?, „Electronic Journal of Comparative Law”, vol. 9.1 (January 2005).

Sharma L.L., Teret S.P., Brownell K.D., The Food Industry and Self-Regulation: Standards to Promote Success and to Avoid Public Health Failures, Am J Public Health. 2010 February; 100(2).

Sokołowski Ł.M., Prawne aspekty wprowadzania nowej żywności na rynek unijny, Poznań 2017.

Van der Meulen B., The anatomy of private food law, (w:) Private food law, B. van der Meulen (red.), Wageningen 2011.

Van der Meulen B., The System of Food Law in The European Union, Deakin Law Review 2009, nr 2.

Wilde P., Self-regulation and the response to concerns about food and beverage marketing to children in the United States, Nutrition Reviews 2009, vol. 67, nr 3.

Wojciechowski P., Informacja o braku zawartości określonych substancji w żywności w regulacjach prawa żywnościowego, „Przegląd Prawa Rolnego”, 2018, nr 1.

Wojciechowski P., Odpowiedzialność za szkodę wyrządzoną przez produkt niebezpieczny żywnościowy pierwotny i przetworzony, Wybrane Problemy, „Studia Iuridica Agraria”, Tom IX 2011. 